Research, part of a Special Feature on Compensation and Reward for Environmental Services in the Tropics

\title{
Trends and Future Potential of Payment for Ecosystem Services to Alleviate Rural Poverty in Developing Countries
}

\author{
$\underline{\text { Jeffrey C. Milder }}^{1,2}, \underline{\text { Sara J. Scherr }}^{2}{\text {, and } \text { Carina Bracer }^{3}}^{3}$
}

\begin{abstract}
Payment for ecosystem services (PES) is a market-based approach to environmental management that compensates land stewards for ecosystem conservation and restoration. Because lowincome households and communities control much of the ecologically sensitive land in developing countries, they potentially stand to gain from PES, as environmentally responsible stewardship is assigned a value by various actors in society. To date, however, instances of PES benefiting the poor have been limited mainly to specific localities, small-scale projects, and a handful of broader government programs. We analyze the size, characteristics, and trends of PES to evaluate its future potential to benefit low-income land stewards in developing countries. We estimate that by the year 2030, markets for biodiversity conservation could benefit 10-15 million low-income households in developing countries, carbon markets could benefit 25-50 million, markets for watershed protection could benefit 80-100 million, and markets for landscape beauty and recreation could benefit 5-8 million. If payments and markets reach these potentials, they could provide a non-negligible contribution to poverty alleviation at the global level.
\end{abstract}

Key Words: biodiversity conservation; carbon sequestration; eco-certification; market development; market policy; payment for ecosystem services; payment for environmental services; poverty alleviation; rural development; watershed protection

\section{INTRODUCTION}

Payment for ecosystem services (PES) is an approach to environmental management that uses cash payments or other compensation to encourage ecosystem conservation and restoration. We define PES to include direct payments from ecosystem service beneficiaries to land stewards, as well as indirect payments earned through eco-certified production (Food and Agriculture Organization 2007). PES as defined here is therefore a subset of compensation and reward for ecosystem services, which is defined and analyzed elsewhere (Swallow et al. 2009). PES is implemented through contingent agreements between land stewards and ecosystem service beneficiaries such as private businesses, communities, and society as a whole (Wunder 2005).

Throughout the developing world, critical ecosystem services are generated on rural lands owned or managed by low-income people, including natural forests, agroforests, farmland, and rangeland (Daily 1997, Molnar et al. 2004). As markets and compensation schemes for ecosystem services are established, low-income land stewards stand to benefit from the increased value placed on the services that these lands provide. Several studies have evaluated the degree to which low-income sellers of ecosystem services have benefitted or could benefit from PES (Landell-Mills and Porras 2002, Grieg-Gran et al. 2005, Pagiola et al. 2005, Food and Agriculture Organization 2007, Scherr et al. 2007b, Pagiola et al. 2008a, Peskett et al. 2008). The results indicate that PES does or could provide important livelihood benefits to poor people at the household or community level, whether in the form of cash payments or noncash benefits such as enabling the transition to more profitable and resilient land-use systems, establishing secure land tenure, or strengthening social capital and supportive local institutions. However, the overall size and effect of pro-poor PES have not been quantified; therefore, the potential for PES to 
alleviate rural poverty at a global scale over the next few decades is largely unknown.

Here, we address this important gap by providing quantitative estimates of the degree to which PES could benefit low-income rural land stewards as sellers of ecosystem services over the next two decades. To do this, we evaluate three aspects of ecosystem service markets: the total potential future size of these markets, the segment of these markets that could involve low-income land stewards, and the level of benefit that low-income people could derive from participation (Fig. 1). PES can also have significant effects on low-income ecosystem service beneficiaries and on PES nonparticipants. For example, urban water users in developing countries could realize benefits (e.g., cleaner water) and incur costs (e.g., higher water cost rates) associated with PES for watershed protection. Similarly, PES nonparticipants could derive indirect benefits from improved ecosystem stewardship on nearby lands or could be harmed by the re-allocation of land tenure and resource use rights associated with PES. These important issues are beyond the scope of our analysis, but are considered in several other studies (e.g., Wunder 2008, Zilberman et al. 2008). In addition, we consider the potential effects of PES only on rural land stewards as providers of ecosystem services; we do not examine nonland-use-based ecosystem service markets or initiatives such as renewable energy projects for generating carbon offsets.

First, we begin by reviewing the current scope and characteristics of PES markets globally with respect to each of the three factors identified above: total market size, pro-poor participation, and pro-poor benefit. Second, we identify and discuss key market and policy patterns and trends that are likely to affect the future development of these aspects of PES. Third, we synthesize this information to estimate the number of low-income land stewards that could participate in each market segment. Finally, we identify key leverage points for realizing the potential of PES to benefit the poor over the next two decades.

\section{TOTAL MARKET SIZE}

To understand opportunities for pro-poor PES, it is helpful to distinguish different segments of the PES market and analyze each according to its distinct attributes. For our purposes, we define a PES typology according to two variables: the type of service being transacted and the identity of the buyer. Market-like transactions have developed around four ecosystem service categories: biodiversity conservation, carbon sequestration, watershed protection, and landscape beauty and recreation (Landell-Mills and Porras 2002). In addition, there are four categories of ecosystem service buyers (Scherr et al. 2004):

1. Public sector buyers: These buyers seek to protect the public good of ecosystem services on behalf of their constituencies. They include local, regional, and national governments, as well as quasi-public agencies such as the World Bank.

2. Private sector buyers under regulatory obligation: These buyers are mandated to offset their environmental impacts by laws such as wetland mitigation requirements or greenhouse gas emissions trading schemes.

3. Private sector buyers acting voluntarily: These buyers may purchase ecosystem services to support their business operations, to maintain a "green" brand image, or to adhere to principles of corporate social responsibility. This category also includes philanthropic buyers such as conservation nongovernmental organizations (NGOs) and individual consumers.

4. Consumers of eco-certified products: These buyers participate in ecosystem service markets by paying a premium for products produced in more environmentally benign ways, such as shade-grown coffee that conserves biodiversity. Although the form of payment is less direct than in the other three categories, this market segment is important for low-income land stewards and is therefore included in our analysis.

Public sector buyers have historically been the largest purchasers of ecosystem services (Food and Agriculture Organization 2007), but this is changing as cap-and-trade programs for carbon, as well as various habitat mitigation schemes, promise to increase the role of private sector buyers acting under regulatory obligation. With this change, the global portfolio of PES is shifting from a preponderance of government programs financed by tax revenue, foreign aid, and loans to a greater 
Fig. 1. Conceptual representation of the key factors influencing the potential of payment for ecosystem services to benefit low-income people. (A) Total size of PES markets, (B) degree to which low-income people can participate in these markets as sellers of ecosystem services, (C) degree to which participants actually benefit.

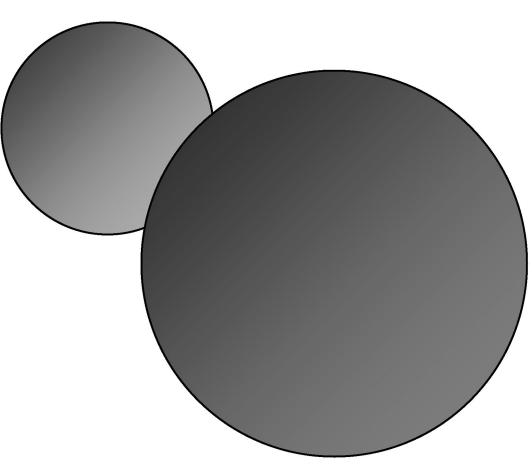

a) How large is the pie?

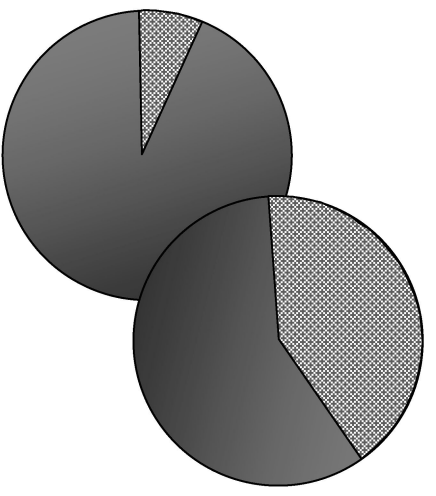

b) How big a slice goes to the poor?

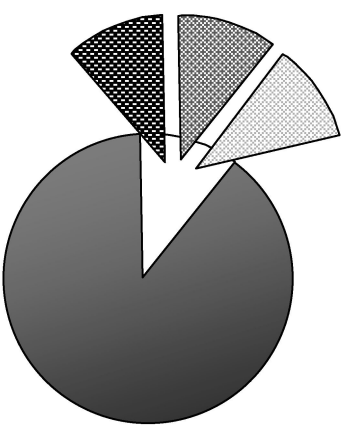

c) How "sweet" is this slice? share of true market instruments driven by private demand and facilitated by the maturation of supporting institutions (Bracer et al. 2007).

We derived size estimates for each market segment by conducting a meta-review of existing PES projects and programs and classifying each project or program into the ecosystem service category that best describes its buyer type and principal conservation objective (Table 1). However, many initiatives, including the large public PES programs in Europe and the United States, tend to purchase "bundles" of multiple environmental services or tend to be ambiguous with regard to the specific services procured. Thus, although the order-ofmagnitude market size calculations are fairly straightforward, the allocation among market segments is subject to differing interpretations.

\section{PRO-POOR PARTICIPATION}

Previous studies have identified a set of four sequential criteria that must be met for low-income households and communities to participate in PES: eligibility to participate, desire to participate, ability to participate, and competitiveness relative to prospective nonpoor sellers of ecosystem services (Pagiola et al. 2005, Wunder 2008).

For low-income land stewards to be eligible to participate in PES, they must manage land or resources that provide or could provide ecosystem services demanded by buyers. Poor people who provide services that are ecologically valuable but not demanded by specific buyers are unlikely to benefit from PES (Southgate and Wunder 2007). Eligibility is also contingent upon satisfying rules or criteria established by the PES market or program. To date, smallholders have been largely excluded from the regulatory carbon market because of limitations and complex rules related to land-use-based projects under the Kyoto Protocol's Clean Development Mechanism (Henman et al. 2008). In addition, some government PES programs 
Table 1. Estimates of market size, buyers, and sellers in various market segments of payment for ecosystem services (PES) as of 2009. See text for explanations of categories and market segments.

\begin{tabular}{lccc}
\hline \hline $\begin{array}{l}\text { Type of payment for } \\
\text { ecosystem services }\end{array}$ & $\begin{array}{c}\text { Market size (million } \\
\text { USD/yr) } \dagger\end{array}$ & Buyer & Seller \\
\hline
\end{tabular}

\section{Biodiversity conservation}
(A) Public sector
$1450 \ddagger(190)$

(B) Private, regulated (capand-trade for terrestrial habitats and species)

(C) Private, voluntary

(corporate social

responsibility, "green"

branding, philanthropic)

(D) Eco-certified forest products

Eco-certified agricultural products
$>$ 5000II $(>120)$

380! (unknown)

$10-17(5-8)$

$>>001(>120)$

42,000II (unknown)
Governments, multilateral organizations
Farmers, forest landowners, other private land stewards
Mitigation banking companies, public agencies, nongovernmental organizations

(NGOs), private land stewards

Private land stewards,

NGOs, private companies,

indigenous and community groups

Certified forest Individual consumers, retailers, industries that use wood and fiber

products producers

Farmers

Individual consumers, retailers, food processing industries
European Union Directorate-General

for Agriculture and

Rural Development

2008, Forest Trends and Ecosystem

Marketplace 2008, U.

S. Natural Resources

Conservation Service Farm Bill

Conservation

Programs§

Environmental Law Institute 2007, program websites

Forest Trends and Ecosystem Marketplace 2008, project websites

Bishop et al. 2008, Forest Trends and Ecosystem Marketplace 2008

Bishop et al. 2008, Forest Trends and Ecosystem Marketplace 2008

World Bank 2007
(A) Public sector
$15 \ddagger(15)$
National governments
Private land stewards multilateral organizations
(B) Private, regulated $\quad<10(<10)$
Regulated industry, governments, carbon funds, brokers, Private landowners,
project developers investors
(C) Private, voluntary
$157(\sim 100)$
Corporations, NGOs, Carbon offset retailers universities, individuals and project developers, conservation NGOs, governments
United Nations Framework Convention on Climate Change\#


(D) Eco-certified products

\section{Watershed protection}

(A) Public sector

(B) Private, regulated

(C) Private, voluntary

(D) Eco-certified products

\section{Landscape beauty and recreation}

(A) Public sector

(B) Private, regulated

(C) Private, voluntary (hunting and fishing fees, access to ecotourism sites)

(D) Eco-certified products
$8-15(5-10)$

See 1DI

$14,200 \$(5500$ in China; 180 in other developing nations)

$1100 \dagger \dagger(<5)$

$5100(<5)$

0

0

\section{Government water and wastewater utilities, other government agencies}

Same as 1D

Same as 1D

Private land stewards, communities, forest companies, public landowners
European Union Directorate-General for Agriculture and Rural Development 2008, Porras et al. 2008, Bennett 2009,

U.S. Natural Resources Conservation Service Farm Bill Conservation Programs§

Private water and wastewater utilities, point source emitters

Private industry (beverage, mining, hydropower, and agribusiness sectors), individuals

Same as 1D

National governments
Farmers, forest landowners, other private land stewards

$$
\mathrm{n} / \mathrm{a}
$$

Tourists, hunters, anglers, commercial tour operators, conservation NGOs

Public and private land owners, communities
Nonpoint source emitters (e.g., farmers, owners of streams), developers of wetland banks

Private land stewards, forest companies, public landowners, cooperatives

Same as 1D
Environmental Law Institute 2007, Porras et al. 2008

Porras et al. 2008, watershedmarkets.org

European Union Directorate-General for Agriculture and Rural Development 2008

$$
\mathrm{n} / \mathrm{a}
$$

Lindsey et al. 2007, Bishop et al. 2008

$\mathrm{n} / \mathrm{a}$

$†$ Global value; value for developing countries in parentheses.

¥Many public sector PES programs promote more than one of the major ecosystem service categories in rural landscapes, making it difficult to segment these payments into individual ecosystem service categories. Such "bundling" or multi-functionality characterizes public-sector PES programs in the European Union, United States, China, Costa Rica, and other countries. We place these multi-objective payments in the category for which they are targeted most specifically, according to the program's enabling legislation, stated goals, or actual implementation. $\S \underline{\text { http://www.nrcs.usda.gov/programs/farmbill/2008/ataglance.html. }}$ 'This number includes habitat banking under the U.S. Endangered Species Act. However, wetland and stream mitigation banking pursuant to Section 404 of the U.S. Clean Water Act are classified under watershed protection because the principal regulatory basis for these markets is the protection and regulation of water quantity and quality. ITThese numbers refer to the total size of the global market for eco-certified forest and agricultural 
products. Some unspecified fraction of this total amount can be considered the premium paid by consumers for the eco-friendly means of production. Biodiversity conservation is the ecosystem service most strongly associated with consumer demand for eco-certified production, but such production can also support watershed protection and carbon sequestration.

\#United Nations Framework Convention on Climate Change projects registered under the Clean Development Mechanism: http://cdm.unfccc.int/Statistics/Registration/RegisteredProjByScopePieChart. html.

$\dagger \dagger$ The vast majority of this market volume is attributable to wetland and stream mitigation under Section 404 of the U.S. Clean Water Act. However, this figure includes only mitigation commitments satisfied by off-site banking and in-lieu payments. It excludes mitigation implemented by land developers themselves, which generally does not involve an ecosystem service payment or market transaction.

historically imposed eligibility criteria that disadvantaged the poor, such as requirements for legal land title and minimum area necessary for enrollment (Grieg-Gran et al. 2005). However, when such requirements are absent, the poor have been able to participate in PES across a variety of settings, even when they are not targeted preferentially (Uchida et al. 2007, Wunder and Albán 2007, Muñoz-Piña et al. 2008, Pagiola et al. 2008a).

Spatial analyses indicate that poor people inhabit many of the lands that generate key ecosystem services in developing countries, suggesting a high degree of potential eligibility (Nelson and Chomitz 2007, Sunderlin et al. 2007, Pagiola et al. 2008b). Thus far, the limited reach of PES worldwide has meant that only a small fraction of these low-income people have actually been able to participate. However, PES initiatives in China have involved perhaps 50 million or more low-income households (Uchida et al. 2007, Bennett 2009). On a smaller scale, low-income land stewards have been eligible to participate in national PES programs in Mexico and Costa Rica, and in many smaller programs and transactions in Latin America, Africa, and Asia (e. g., Landell-Mills and Porras 2002, Pagiola et al. 2004, Wunder and Albán 2007, Muñoz-Piña et al. 2008).

Land stewards who are eligible to participate in PES will generally desire to do so only if they perceive such participation to be economically beneficial. This will often be the case when the opportunity cost of participation is low or negative. For example, in "asset-building" PES schemes (Wunder 2008), land stewards receive payments for investing in management activities that may yield long-term livelihood benefits, such as agroforestry or conservation agriculture. Indeed, such co-benefits are often critical for motivating participation in PES with low per-hectare payment amounts, such as soil carbon sequestration on agricultural lands (Antle and Stoorvogel 2008, Graff-Zivin and Lipper 2008). The desirability calculus for many low-income households includes not only the opportunity cost of participation, but also the effect on household risk, labor requirements, and income diversification and timing (Lipper and Cavatassi 2004). Household decisions may also be subject to higher discount rates than conventional economic analysis.

Low-income land stewards who are eligible and wish to participate in PES must still possess the skills, knowledge, resources, and tenure rights to enter into PES agreements and to deliver ecosystem services reliably. These factors are especially critical if the payment is contingent on actively implementing specific management activities, such as reforestation. The barriers to land-use investment for low-income households are well known and include a lack of access to capital or credit, poorly defined property rights, high discount rates, and risk aversion (Lipper and Cavatassi 2004, Wunder 2008). At the community level, significant barriers might include lack of social capital, lack of administrative capacity, and lack of previous experience with market transactions. Despite these hurdles, participation can be facilitated by providing clear guidance on the management options that will yield payments, access to extension and technical assistance, and capacity building for local institutions. For example, poor and very poor farmers in Nicaragua have been able to participate in an asset-building PES scheme that involved transitions to intensive silvopastoral management 
systems (Pagiola et al. 2008a). In addition, marginalized populations are the main PES recipients in Mexico's payment for hydrological services program (Muñoz-Piña et al. 2008).

The final consideration for pro-poor participation is the competitiveness of low-income land stewards relative to nonpoor suppliers of ecosystem services. Competitiveness is important when either poor or nonpoor land stewards could supply a particular demanded service. This is always the case with carbon sequestration but only sometimes the case with location-specific watershed protection, biodiversity conservation, and landscape beauty services. Because the poor tend to control small tracts of land, they are often at a competitive disadvantage because they have higher per-unit transaction costs than do larger landowners, who can sell a greater volume of ecosystem services per transaction (Pagiola et al. 2005, Hamilton et al. 2007). In Indonesia, for example, carbon payments for smallholders were found to be feasible for farmers managing plots of 1.6 ha or larger, but infeasible for smaller farmers because of the proportionally higher transaction costs (Cacho and Lipper 2006). However, these costs can be reduced through group participation schemes, cost-effective monitoring, improved information exchange, and subsidies from governments, NGOs, or aid programs (Smith and Scherr 2003).

In contrast, the poor may be at a competitive advantage in PES markets that favor multi-objective projects providing social equity or sustainable development benefits. Instead of targeting PES strictly to maximize the cost-effectiveness of ecosystem service procurement, these contracts typically pay a premium for ecosystem services sourced from projects that provide social cobenefits without sacrificing the quality or reliability of the ecosystem services. Social co-benefits are already an important aspect of PES programs and market segments such as the World Bank's BioCarbon Fund, portions of the voluntary and regulated carbon markets, and biodiversity offset projects in developing countries (World Bank 2007, Business and Biodiversity Offset Programme 2008, Hamilton et al. 2008).

\section{PRO-POOR BENEFITS}

The aggregate benefit of PES for the poor depends not only on the total number of poor people who participate, but also on the magnitude of benefits that these participants derive. Empirically, poor people who participate in PES generally receive a net positive level of benefits from cash payments and/or other livelihood enhancements (Molnar et al. 2007). In a review of more than six studies of Latin American PES programs, Wunder (2008) found that the benefits were significant in all cases, with payments composing $10 \%$ to $>50 \%$ of household income. Household-level effects associated with China's Sloping Land Conversion Program have been more variable: although the program reached millions of low-income households with an overall positive effect (Uchida et al. 2007), payments were sometimes not fully delivered or were less than farmers' opportunity costs (Bennett 2008). In general, when PES does not benefit participants, it is because participation is not truly voluntary (Wunder et al. 2005).

The level of payment that sellers receive depends partially on their ability to negotiate a fair price. Access to market information and supportive local institutions can improve the bargaining position of rural land stewards and communities (Scherr et al. 2004). When poor people manage unique or nonsubstitutable resources such as endemic biodiversity, their bargaining power will be significant. However, for services that are more fungible, particularly carbon sequestration, prices will be dictated by larger market forces, and poor people may find little flexibility in the price offered.

Because PES often provides only supplemental income to low-income sellers of ecosystem services, an important aspect of pro-poor benefit is the extent to which participation enhances or undermines the broader livelihood strategies for the service providers. Ideally, market participation will increase stocks of natural, social, and human capital at the household and community level while improving resilience to environmental and economic shifts. Thus, in the context of the rural poor, PES should, and often does, constitute "coinvestment in assets," in which the payment itself is part of a broader strategy encompassing both environmental stewardship and sustainable livelihoods (van Noordwijk et al. 2007). 


\section{TRENDS SHAPING THE POTENTIAL BENEFIT TO THE POOR FROM PAYMENT FOR ECOSYSTEM SERVICES}

As PES markets evolve and grow, the conditions and patterns discussed above are subject to rapid transformation as a result of global trends; market development; and scientific, institutional, and policy innovations. We next discuss some of the most critical trends, processes, and innovations that are likely to shape pro-poor PES.

\section{Regulatory framework}

Environmental regulations are the basis for cap-andtrade programs that drive much of the private sector demand for ecosystem services. International regulation of carbon emissions continues to expand, with cap-and-trade programs under debate in the United States, Australia, and New Zealand. Expanded regulatory frameworks for carbon are likely to spur new demand for carbon offsets from developing countries, but the potential benefit to the poor depends heavily on the extent to which these regulations allow offsets from land use, land-use change, and forestry (LULUCF). Biodiversity conservation and watershed protection regulations remain weak or nonexistent in most developing countries. However, if developed country frameworks for environmental mitigation and offsetting are replicated or adapted in developing countries, significant new ecosystem service markets benefitting the rural poor could emerge.

\section{Public sector programs and subsidies}

Driven in part by international trade agreements that limit the use of conventional commodity price supports, many countries are revising their agricultural policies to replace or supplement such programs with agri-environmental payments. This trend is most pronounced in developed countries, but is also seen in middle-income countries such as South Africa and Mexico, and could continue to increase the magnitude of public-funded PES in agricultural areas (Food and Agriculture Organization 2007). Multilateral development banks, aid agencies, and the Global Environment Facility have also played an important role in piloting pro-poor PES and experimenting with new innovations (e.g., Pagiola et al. 2004, World Bank 2007); projects by these types of organizations are likely to continue to fulfill this role. Multilateral environmental agreements such as the Convention on Biological Diversity, Convention to Combat Desertification, United Nations Framework Convention on Climate Change, and Ramsar are also considering PES as a mechanism to achieve convention objectives. Some governments and NGOs involved in these processes are proposing PES strategies that would favor lowincome land stewards (Bracer et al. 2007).

\section{Industry and consumer preferences}

Many corporations and consumers who purchase ecosystem services for reasons of individual ethics or corporate social responsibility tend to favor projects that provide multiple environmental and social benefits. Corporate social responsibility and public relations are currently the biggest motivators for buyers in the voluntary carbon markets. Europe's continuing participation in these markets suggests that robust regulated carbon markets need not undermine voluntary markets that serve buyers who wish to demonstrate ethical behavior (Hamilton et al. 2007, 2008). With the recent proliferation of third-party standards that differentiate projects with social and environmental co-benefits, the portion of the carbon market benefitting the poor appears poised to expand (Hamilton et al. 2008). The standards that require social benefits and apply to LULUCF projects such as Plan Vivo, Social Carbon, and the Climate, Community, and Biodiversity Standards are breaking important ground by demonstrating how projects that benefit rural communities can be developed and sold in the global marketplace (Hamilton et al. 2008).

\section{Land and resource tenure}

PES is predicated on clear notions of land and resource control and excludability at the individual or community level. Without such security, land stewards may have difficulty managing land for ecosystem services, claiming compensation for the services provided, and integrating ecosystem services with other productive activities to assemble a viable livelihood strategy (Grieg-Gran et al. 2005). In recent years, national and international policy processes, under pressure from community and indigenous rights groups, have established or formalized tenure rights for low-income rural people and communities in many parts of the world (Molnar et al. 2004). However, there are still many regions where such rights have not been formalized. 


\section{Development and evolution of local institutions}

Engaging in ecosystem service markets can be extremely complex, requiring technical, scientific, financial, and negotiation skills. Local institutions that can demystify PES and help communities address these challenges are critical to allow lowincome stakeholders to participate and negotiate favorable terms in PES agreements. Local institutions can also be important for facilitating collective action to allow smallholders to compete against larger service providers in national or global markets. Finally, collective management approaches may be necessary for supplying ecosystem services that are mediated at a landscape scale, including biodiversity conservation, watershed protection, and landscape beauty (Swallow et al. 2005). Governments, development agencies, and NGOs can help establish such institutions or expand the capacity of existing institutions to serve these functions.

\section{Scientific research and knowledge sharing}

Scientific research documenting the links between ecosystem functioning and human well-being can motivate demand for ecosystem services by helping prospective beneficiaries understand the importance of investing in such services. Research is also needed to improve systems for monitoring, verifying, and quantifying the provision of ecosystem services so that buyers feel confident that they are receiving the services they purchase (Scherr et al. 2007a). Biodiversity has proven especially difficult to measure and convert into tradable equivalency units (Agius 2001). Finally, research and extension can help low-income land stewards identify management practices that provide ecosystem services while maintaining flows of ecosystem goods such as timber or agricultural products (Scherr and McNeely 2008).

\section{POTENTIAL FOR PAYMENT FOR ECOSYSTEM SERVICES TO ALLEVIATE POVERTY OVER THE NEXT TWO DECADES}

We next evaluate the four main ecosystem service markets and identify those market segments with the greatest potential for developing benefits to the poor. We conducted an order-of-magnitude analysis of the potential size of each market sector by analyzing data on recent market growth trends, policy and market drivers of future demand from each buyer group, and factors influencing the degree to which demanded ecosystem services could be provided by low-income land stewards (Table 2).

\section{Biodiversity conservation}

Overall, we estimate that markets for biodiversity conservation could benefit 10-15 million lowincome households annually by 2030 . Biodiversity conservation services are highly location specific; buyers are generally interested in conserving only those habitats and species that are rare, endangered, in excellent condition, or have high potential for restoration (Wunder 2008). Throughout the developing world, however, low-income and indigenous communities occupy many of the most biodiverse and threatened lands (Molnar et al. 2004). Thus, the poor may be the suppliers of choice simply by virtue of their location, particularly in the voluntary biodiversity markets in which buyers such as conservation NGOs are likely to use strict resource-based targeting.

Historically, government agencies have been the biggest buyers of biodiversity conservation services. However, the large majority of these payments have been in developed countries, and most have been allocated to nonpoor farmers who agree to scale back or cease agricultural operations on their land. It is unlikely that a comparably large set of public-sector payment schemes will emerge in developing countries simply because of budget constraints. However, we predict that a growing number of middle-income countries will establish and expand government PES for biodiversity or multiple objectives, as has already occurred in South Africa and Costa Rica (Turpie et al. 2008).

The enactment of environmental regulations could allow developing countries to stimulate new biodiversity markets without spending large sums of money. For example, Brazil's Forest Regulation establishes a legal framework to limit total forest clearance while enabling the trading of development rights on rural forest lands. Similarly, governments could require biodiversity offsets for large development projects such as mines, pipelines, plantations, and dams (ten Kate et al. 2004). In the near term, such offsets could be implemented through the environmental impact assessment process, which is already in place in many developing countries. At the same time, industry 
Table 2. Potential for each market sector of payment for ecosystem services to benefit low-income households and communities in developing countries within the next two decades. $\dagger$

\begin{tabular}{lcccc}
\hline \hline & \multicolumn{4}{c}{ Buyer } \\
\cline { 2 - 5 } Ecosystem service & Public sector & Private, regulated & Private, voluntary & $\begin{array}{c}\text { Consumers of eco- } \\
\text { certified products }\end{array}$ \\
\hline Biodiversity conservation & $\mathrm{XX}$ & $\mathrm{XXX}$ & $\mathrm{XX}$ & $\mathrm{XXX}$ \\
Watershed protection & $\mathrm{XXXX}$ & $\mathrm{XX}$ & $\mathrm{XX}$ & $\mathrm{X}$ \\
Carbon & $\mathrm{X}$ & $\mathrm{XXXX}$ & $\mathrm{XXX}$ & $\mathrm{X}$ \\
Landscape beauty or recreation & $\mathrm{XX}$ & 0 & $\mathrm{XXX}$ & $\mathrm{X}$ \\
\hline
\end{tabular}

$\dagger$ These are not predictions, but rather estimates of the number of low-income people that each market sector could benefit if the identified actions necessary to shape payment for ecosystem services to benefit low-income stakeholders are largely successful.

XXXX - Tens of millions of low-income providers could benefit.

XXX - Millions of low-income providers could benefit.

$\mathrm{XX}$ - Hundreds of thousands of low-income providers could benefit.

$\mathrm{X}$ - Fewer than 100,000 low-income providers are likely to benefit.

0 - The sector is unlikely to develop or will affect only a few low-income providers.

self-regulation of biodiversity impacts is advancing through forums such as the commodity roundtables (e.g., for palm oil and soybean) and international lending criteria (e.g., the Equator Principles). Such guidelines could generate sizable private voluntary markets for biodiversity conservation while building a knowledge base and market infrastructure for transitioning to regulatory markets.

Presently, most biodiversity offsets are supplied by large landowners or firms that have the skills and financing to establish marketable habitat banks. Low-income communities are unlikely to become competitive suppliers of habitat mitigation banks that require expertise in ecological restoration and permitting. However, to the extent that they control land in biodiverse areas and have low opportunity costs, such communities could be competitive suppliers of biodiversity compensation areas or reserves in which the management focus is on conserving the existing resources.

Consumer-driven markets for eco-certified agricultural and forestry products offer the greatest potential for low-income producers to benefit monetarily from biodiversity-friendly stewardship. For example, 25 million small-scale producers worldwide currently grow coffee, and it is conceivable that $20 \%$ of these farmers could participate in eco-certified production by 2030 (Forest Trends and Ecosystem Marketplace 2008). Participation of small farmers in eco-certified agriculture remains a challenge because of the high costs of certification and monitoring in working with small landowners. However, group certification systems and other protocols are being created and refined to address these issues.

\section{Carbon sequestration}

Carbon markets have significant potential to benefit low-income land stewards. We estimate that 25-50 million low-income households could participate by 2030. This participation could be doubly beneficial if carbon sequestration were achieved through assetbuilding practices such as agroforestry and conservation agriculture, which can enhance natural resource-based livelihoods and increase smallholders' 
resilience to drought, climate change, and economic instability.

From the supply side, there is ample capacity to sequester carbon on rural lands worldwide, including those managed by low-income people. The Intergovernmental Panel on Climate Change (2007) estimates the potential for carbon mitigation in developing countries at $1.9 \mathrm{Gt} / \mathrm{yr}$ of $\mathrm{CO}_{2}$ equivalent from the agriculture sector and $1.6 \mathrm{Gt} / \mathrm{yr}$ from the forestry sector by 2030 , assuming a market price of $\$ 50 / \mathrm{t}$ of $\mathrm{CO}_{2}$ equivalent.

From the demand side, the challenge is to create a market for land-use-based carbon credits that is accessible to low-income people. The carbon market is among the world's largest commodity markets, but currently only a tiny fraction of this volume is for LULUCF offsets, potentially affecting rural land stewards. Within the Kyoto Protocol's Clean Development Mechanism, afforestation and reforestation are the only allowable source of landuse-based carbon credits, representing only 6 of the 1726 Clean Development Mechanism projects registered to date, totaling less than $\$ 10$ million of the $\$ 125$-billion regulatory carbon market (Capoor and Ambrosi 2009; United Nations Framework Convention on Climate Change projects registered under the Clean Development Mechanism: http://cd m.unfccc.int/Statistics/Registration/RegisteredProj ByScopePieChart.html). Furthermore, LULUCF projects are specifically excluded from the current EU emissions trading system, as well as the proposed Australia and New Zealand systems (Capoor and Ambrosi 2009).

A second challenge is the tendency of carbon offset buyers, brokers, banks, and other institutions to favor service providers who can offer large volumes with low transaction costs and little uncertainty (Grieg-Gran et al. 2005, Locatelli et al. 2008). Thus, carbon offsets have tended to focus on industrial gas reduction, renewable energy, and energy efficiency projects (Capoor and Ambrosi 2008) and, even in the realm of LULUCF offsets, to favor large-scale projects such as plantation establishment and major conservation set-asides that provide few benefits to low-income communities. Additional work is therefore needed to build and support intermediary institutions that can aggregate carbon credits from small landowners and package them for large buyers who are unwilling to accept the additional risks and costs currently associated with sourcing carbon credits from smallholders.
The future of the regulated carbon markets is under negotiation, and the parties appear poised both to allow carbon offsets from additional types of LULUCF projects, principally by reducing emissions from deforestation and forest degradation (REDD), and to create more effective mechanisms for facilitating these activities (Angelsen et al. 2009). Ebeling and Yasué (2008) estimate that REDD could generate $\$ 32$ billion in carbon mitigation payments annually, assuming a future carbon price of $\$ 21 / \mathrm{t}$ of $\mathrm{CO}_{2}$ equivalent. A growing set of stakeholders is pushing for an even broader set of LULUCF options from agriculture, forestry, and other land uses. The inclusion of additional LULUCF mitigation opportunities in global carbon regulations could significantly increase the participation of low-income communities in these markets, provided that other hurdles in the Clean Development Mechanism are also overcome.

Although the voluntary carbon market is much smaller than the regulatory market, its importance to low-income communities has been greater (Bayon et al. 2007, Hamilton et al.2009). From 2006 to 2008, the voluntary carbon market grew from $\$ 100$ million to $\$ 705$ million, including approximately $\$ 150$ million in LULUCF offsets, and rapid growth is expected to continue (Hamilton et al. 2009). We expect this market segment to remain important for the poor because of voluntary buyers' frequent interest in multi-benefit projects that are appealing for corporate social responsibility and public relations purposes. Experience gained from current efforts to establish standards and methodologies for credible, transparent multibenefit LULUCF projects for the voluntary market could provide a head start for designing projects for future regulated markets. If regulated carbon markets develop to allow land-use-based offsets from developing countries, the pro-poor component of these markets eventually could far exceed that of the voluntary markets.

\section{Watershed protection}

Overall, we estimate that watershed protection PES could benefit 80-100 million low-income households by 2030 . Historically, the public sector has been the largest buyer of watershed protection services, and we expect this trend to continue. To the extent that flood protection and access to clean water are public goods, the task of ensuring these 
goods usually falls to the government. The first generation of watershed PES programs in developing countries was heavily underwritten by foreign aid, loans, and international NGOs (Food and Agriculture Organization 2007). However, many of the larger programs, such as those in Mexico, Costa Rica, and Colombia, are now funded mainly by domestic sources from municipal water and electricity rate-payers, private water users, and general tax revenue. China's massive Sloping Land Conversion Program ( $\$ 45$ billion over 10 years) and other national and provincial PES programs in China are also funded domestically, suggesting that water-stressed, middle-income countries may be increasingly willing to self-finance large-scale PES when it is in their interest to do so.

In theory, private buyers acting on a voluntary basis should be motivated to protect watersheds to safeguard business assets such as hydroelectric reservoirs, industrial water sources, and irrigation water sources. In practice, however, the amount of revenue generated by such transactions has been relatively small (Forest Trends and Ecosystem Marketplace 2008, Porras et al. 2008). Voluntary watershed markets are likely to grow as the clean and abundant water upon which businesses depend becomes an increasingly scarce resource in some regions. However, current impediments to market development are likely to remain, for example, the tendency of ecosystem service beneficiaries to freeride and the inability of service providers to exclude users from accessing the resource for free (Pagiola 2008). For this reason, we expect this market segment to benefit fewer than one million lowincome land stewards by 2030 .

Regulatory private markets such as water quality trading schemes have been limited to the United States, Australia, and Canada, and have benefited few poor people. Given that water pollution is a serious problem in many developing countries, it is possible that similar schemes will eventually emerge elsewhere. However, because of the complexity and administrative requirements of such regulations, we predict that they will not emerge on a large scale in developing countries over the next two decades.

\section{Landscape beauty and recreation}

In this market segment, low-income land managers are compensated for their stewardship of landscapes or wildlife that have scenic or recreational values to tourists, hunters, or fishers. For example, in and around protected areas, local communities may receive a portion of visitor fees in exchange for helping to protect or refraining from harming wildlife or scenic values. Alternatively, they may receive payments directly from tour operators for maintaining certain land uses or protecting or enhancing geographic features or charismatic species that appeal to tourists. In either case, the benefits are usually limited to communities living in or adjacent to tourist attractions or who are near enough to transport infrastructure to attract recreational users. In total, we estimate that these markets could benefit five to eight million lowincome households by 2030 .

Tourism is the world's largest industry and is growing at $4.4 \% / y r$, while ecotourism is growing at perhaps three times this rate (Bishop et al. 2008, World Travel and Tourism Council 2008). The rapid growth in demand combined with the increasing scarcity of beautiful rural landscapes and wildlife in many countries would appear to create fertile conditions for markets involving landscape beauty and recreation to develop and expand. However, rural land stewards who seek benefits for maintaining landscape beauty often suffer from the problem of nonexcludability; that is, they cannot prevent users from enjoying these services for free. As a result, many payments for landscape beauty and recreation to date have been more similar to benefit-sharing schemes or community-based natural resource management than true PES.

Although there are several factors currently limiting the pro-poor potential of this market segment, these issues are not insurmountable. First, rural communities must have the right to control access to scenic and recreational resources and to enter into agreements with tour companies and other users to purchase access rights. In cases in which such rights have been established, wildlife and local communities alike have often benefited. For example, Zimbabwe's CAMPFIRE program for wildlife management yielded $\$ 20$ million from sales of wildlife access rights to hunting and safari operators, benefitting 120,000 households over a 12-year period (Frost and Bond 2008). Second, hunting, fishing, and park entrance fees collected 
by government agencies could be better targeted so that instead of being channeled to general revenue funds, the fees support sustainable management of the resources through payments to local resource stewards. Third, many rural communities will require additional technical support to manage tourism and recreation demand and to capture an equitable portion of the revenue that these activities generate (Bishop et al. 2008). Finally, in cases in which resource stewardship is provided at the community level, fair and transparent systems are needed to avoid corruption and to disperse revenue to individual beneficiaries or legitimate communitylevel investments (Lindsey et al. 2007).

\section{CONCLUSIONS}

These numbers represent best current estimates of the size and shape of pro-poor ecosystem service payments and markets, but they are very much in flux. There is a flurry of new initiatives in the pipeline from agencies such as international development banks, the Global Environment Facility, the United Nations Development Programme, and the United Nations Environment Programme; national and municipal governments; private investment firms; and companies seeking to secure critical natural resources or offset environmental impacts.

Exactly how low-income groups will be involved in these initiatives, and what real benefits they will receive from doing so, is unknown. As enumerated here, ecosystem service markets present many potential opportunities for low-income land stewards in developing countries. If these markets reach their maximum pro-poor potential, it is conceivable that as many as 150 million low-income households (600-800 million rural poor) in developing countries could participate by 2030 . As such, these markets could benefit a substantial portion of the two billion rural poor worldwide who live on less than $\$ 2 /$ day. This would represent annual payments to rural households and communities on the order of $\$ 20-30$ billion/yr, again, a non-negligible contribution compared to the $\$ 120$ billion in Official Development Assistance provided in 2008 (Organisation for Economic Cooperation and Development, unpublished data, htt p://www.oecd.org/dataoecd/48/34/42459170.pdf).

Without proactive efforts to shape ecosystem service payment systems and markets, however, there is no reason to believe that low-income land stewards will receive more than a small share of the total spending. Rather, more powerful groups will capture benefits through privileged roles in shaping the rules, access to technical and market information, access to capital for investment and institutional development, and economies of scale in organization. As ecosystem service markets grow and consolidate, the current situation represents what is likely to be a brief window of opportunity to influence evolving market institutions in ways that will realize their potential to benefit the poor. Many of the key leverage points for fostering propoor PES have been highlighted in other recent articles; these include actions by governments, NGOs, and pro-poor advocates in the areas of policy design, institutional support, scientific research, and project innovation (Table 3 ).

In conclusion, we highlight two especially important factors that will influence the pro-poor potential for ecosystem service markets. The first is the future of international agreements and national legislation for climate action. Agriculture and land use offer one of the greatest short-term opportunities to reduce and sequester greenhouse gases on a large scale. Linking LULUCF sequestration financed by major emitting countries and companies directly with initiatives for climate adaptation and the Millennium Development Goals could benefit large numbers of low-income land stewards by helping them restore degraded lands and forests and convert to more productive, sustainable farming systems (Scherr and Sthapit 2009). Although REDD advocates have strongly promoted avoiding deforestation in climate action frameworks, there is as yet no comparable international advocacy effort to mobilize carbon sequestration by farmers and farming communities linked to poverty reduction. However, the scale of pro-poor participation in the carbon markets depends heavily on the availability of a range of LULUCF mitigation options, including those associated with agriculture.

The second short-term policy priority to support pro-poor PES is to address the tenure rights of the poor in relation to markets. The allocation of rights to manage, buy, and sell ecosystem services is still poorly defined in most countries; in some places, the prospect of new revenue sources from ecosystem service markets is encouraging governments to claim such rights for themselves or for elite political allies. Equitable and well-defined tenure rights can help ensure that PES does not 
Table 3. Key leverage points for shaping pro-poor payment for ecosystem services (PES). We define these as factors that are both critical to the future shape of ecosystem service markets and amenable to influence through programs of advocacy, support, or investment.

\section{A. Increase market size}

A1. Global carbon regulation

A2. Biodiversity regulations

A3. Land use-watershed protection nexus

A4. Eco-certified production
Establish a robust legal framework to regulate carbon emissions worldwide, including provisions for land use, land-use change, and forestry (LULUCF) carbon offsets

Enact requirements to mitigate or offset effects on biodiversity of development projects in developing countries

Increase scientific research on the effects of land use on water quantity and quality

Support market development and methods for smallholder participation
Streck et al. 2008

ten Kate et al. 2004, Bishop et al. 2008

Calder 2002

Molnar et al. 2007

Locatelli et al. 2008

Provide credible yet simple LULUCF and reducing emissions from deforestation and forest degradation (REDD) carbon offset options in postKyoto global carbon regulation

B2. "Best practices" for pro-poor Develop guidelines for design of PES to enable program design the poor to participate

\section{B3. Property rights}

B4. Extension for PES

B5. Local institutional development

B6. Intermediaries

B7. Cost-effective monitoring

B8. Standards
Accelerate efforts to grant clear property rights over land and natural resources to rural individual and community land stewards

Integrate education on ecosystem service management and PES into agricultural extension programs

Support existing farmers' groups, local governments, and nongovernmental organizations to organize and administer the production and sale of ecosystem services

Establish and support intermediary brokers, consolidators, and insurers of ecosystem services generated by smallholders

Develop and test credible low-cost methodologies and information management systems to measure and verify ecosystem service provision from numerous small plots of land

Incorporate minimum standards for social and environmental sustainability into all PES projects while supporting ongoing innovation for more rigorous voluntary standards
Bracer et al. 2007, Smith and Scherr 2003

Sunderlin et al. 2008

Scherr et al. $2007 b$

Scherr et al. $2007 b$

Bracer et al. 2007, Smith and Scherr 2003

Brown 2002, Kremen and Ostfeld 2005, Scherr et al. 2007a

Kollmuss et al. 2008 
C. Increase the pro-poor benefit for those who participate

$\begin{array}{lll}\text { C1. Property rights } & \text { See B3 } & \text { See B3 }\end{array}$

$\begin{array}{lll}\text { C2. Local institutional } & \text { See B5 } & \text { See B5 }\end{array}$ development

become a cause for resource appropriation that dispossesses low-income land stewards. At the same time, these rights provide the basis for the rural poor to enter into mutually beneficial ecosystem service contracts with willing buyers.

Responses to this article can be read online at:

http://www.ecologyandsociety.org/voll5/iss2/art4/responses/

\section{Acknowledgments:}

We thank the staff of Forest Trends and the Katoomba Group's Ecosystem Marketplace for providing information on market trends, and Sajal Sthapit and Hannah Murray for research assistance. We are grateful to the IDRC's Rural Poverty and Environment Group for financial support, and to Brent Swallow for managing the CRES scoping project.

\section{LITERATURE CITED}

Agius, J. 2001. Biodiversity credits: creating missing markets for biodiversity. Environmental and Planning Law Journal 18(5):481-504.

Angelsen, A., S. Brown, C. Loisel, L. Peskett, C. Streck, and D. Zarin. 2009. Reducing emissions from deforestation and forest degradation (REDD): an options assessment report. Meridian Institute, Washington, D.C., USA. [online] URL: http://www REDD-OAR.org.

Antle, J. M., and J. J. Stoorvogel. 2008. Agricultural carbon sequestration, poverty, and sustainability. Environment and Development Economics 13(3):327-352.
Bayon, R., A. Hawn, and K. Hamilton, editors. 2007. Voluntary carbon markets: an international business guide to what they are and how they work. Earthscan, London, UK.

Bennett, M. T. 2008. China's sloping land conversion program: institutional innovation or business as usual? Ecological Economics 65 (4):699-711.

Bennett, M. T. 2009. Markets for ecosystem services in China: an exploration of China's "ecocompensation" and other market-based environmental policies. Forest Trends, Washington, D.C., USA. [online] URL: http://www.efdinitiative.org/research/ publications/publications-repository/markets-forecosystem-services-in-china.

Bishop, J., S. Kapila, F. Hicks, P. Mitchell, and F. Vorhies. 2008. Building biodiversity business. Shell International Limited and the International Union for Conservation of Nature, London, UK, and Gland, Switzerland. [online] URL: http://www.iucn. org/dbtw-wpd/edocs/2008-002.pdf.

Bracer, C., S. Scherr, A. Molnar, M. Sekher, B. O. Ochieng, and G. Sriskanthan. 2007. Organization and governance for fostering propoor compensation for environmental services. ICRAF Working Paper Number 39. World Agroforestry Centre, Nairobi, Kenya.

Brown, S. 2002. Measuring, monitoring, and verification of carbon benefits for forest-based projects. Philosophical Transactions of the Royal Society A 360(1797):1669-1683.

Business and Biodiversity Offset Programme. 2008. Biodiversity offsets and the business and biodiversity offsets programme (BBOP): a draft consultation paper for discussion and comment. United Nations Environment Programme, Nairobi, 
Kenya. [online] URL: http://www.forest-trends.org/ biodiversityoffsetprogram/documents/UNEP/BBOPUNEP-CBD-COP-9-Inf-29.pdf.

Cacho, O., and L. Lipper. 2006. Abatement and transaction costs of carbon-sink projects involving smallholders. ESA Working Paper Number 06-13. Food and Agriculture Organization, Rome, Italy. [online] URL: ftp://ftp.fao.org/docrep/fao/009/ah632e/ ah632e00.pdf.

Calder, I. R. 2002. Forests and hydrological services: reconciling public and science perceptions. Land Use and Water Resources Research 2:2.1-2.12. [online] URL: http://www.luwrr.com/u ploads/paper02-02.pdf.

Capoor, K., and P.Ambrosi. 2008. State and trends of the carbon market 2008. World Bank, Washington, D.C., USA.

Capoor, K., and P.Ambrosi. 2009. State and trends of the carbon market 2009. World Bank, Washington, D.C., USA.

Daily, G. C., editor. 1997. Nature's services: societal dependence on natural ecosystems. Island Press, Washington, D.C., USA.

Ebeling, J., and M. Yasué. 2008. Generating carbon finance through avoided deforestation and its potential to create climatic, conservation and human development benefits. Philosophical Transactions of the Royal Society $B \mathbf{3 6 3}$ (1498):1917-1924.

Environmental Law Institute. 2007. Mitigation of impacts to fish and wildlife habitat: estimating costs and identifying opportunities. Environmental Law Institute, Washington, D.C., USA. [online] URL: http://www.elistore.org/reports view.asp?file=/Data/ products/d17 16.pdf.

European Union Directorate-General for Agriculture and Rural Development. 2008. Rural development in the European Union: statistical and economic information: report 2008. European Commission, Brussels, Belgium. [online] URL: htt p://ec.europa.eu/agriculture/agrista/rurdev2008/index en. $\underline{\mathrm{htm}}$.

Food and Agriculture Organization. 2007. The state of food and agriculture. Food and Agriculture
Organization, Rome, Italy. [online] URL: ftp://ftp.f ao.org/docrep/fao/010/a1200e/a1200e00.pdf.

Forest Trends and Ecosystem Marketplace. 2008. Payments for ecosystem services: market profiles. Forest Trends and Ecosystem Marketplace, Washington, D.C., USA. [online] URL: http://ecos ystemmarketplace.com/documents/acrobat/ PES Matrix Profiles PROFOR.pdf.

Frost, P. G. H., and I. Bond. 2008. The CAMPFIRE programme in Zimbabwe: payments for wildlife services. Ecological Economics $\mathbf{6 5}$ (4):776-787.

Graff-Zivin, J., and L. Lipper. 2008. Poverty, risk, and the supply of soil carbon sequestration. Environment and Development Economics 13 (3):353-373.

Grieg-Gran, M., I. Porras, and S. Wunder. 2005. How can market mechanisms for forest environmental services help the poor? Preliminary lessons from Latin America. World Development 33 (9):1511-1527.

Hamilton, K., R. Bayon, G. Turner, and D. Higgins. 2007. State of the voluntary carbon markets 2007: picking up steam. Ecosystem Marketplace and New Carbon Finance, Washington, D.C., USA, and London, UK. [online] URL: http:// ecosystemmarketplace.com/documents/acrobat/ $\underline{\text { StateoftheVoluntaryCarbonMarket18July Final.pdf }}$

Hamilton, K., M. Sjardin, T. Marcello, and G. Xu. 2008. Forging a frontier: state of the voluntary carbon markets 2008. Ecosystem Marketplace and New Carbon Finance, Washington, D.C., USA, and New York, New York, USA. [online] URL: http:// WWw.ecosystemmarketplace.com/documents/ cms documents/2008 StateofVoluntaryCarbonMarket2. pdf.

Hamilton, K., M. Sjardin, A. Shapiro, and T. Marcello. 2009. Fortifying the foundation: state of the voluntary carbon markets 2009. Ecosystem Marketplace and New Carbon Finance, Washington, D.C., USA, and New York, New York, USA. [online] URL: http://www.ecosystemmarketplace.com/ documents/cms documents/ StateOfTheVoluntary CarbonMarkets 2009.pdf. 
Henman, J. E., S. P. Hamburg, and A. A. Salazar Vega. 2008. Feasibility and barriers to entry for small-scale CDM forest carbon projects: a case study from the northeastern Peruvian Amazon. Carbon and Climate Law Review 3/2008:254-263.

Intergovernmental Panel on Climate Change. 2007. Summary for policymakers. Pages 1-24 in B. Metz, O. R. Davidson, P. R. Bosch, R. Dave, and L. A. Meyer, editors. Climate change 2007: mitigation of climate change. Cambridge University Press, Cambridge, UK. [online] URL: http://www.ipcc.ch/pdf/assessment-report/ar4/wg3/ ar4-wg3-spm.pdf.

Kollmuss, A., H. Zink, and C. Polycarp. 2008. Making sense of the voluntary carbon market: a comparison of carbon offset standards. World Wildlife Fund Germany, Berlin, Germany. [online] URL: http://assets.panda.org/downloads/vem repo rt final.pdf.

Kremen, C., and R. S. Ostfeld. 2005. A call to ecologists: measuring, analyzing, and managing ecosystem services. Frontiers in Ecology and the Environment 3(10):540-548.

Landell-Mills, N., and I. T. Porras. 2002. Silver bullet or fool's gold? A global review of markets for forest environmental services and their impact on the poor. International Institute for Environment and Development, London, UK.

Lindsey, P. A., P. A. Roulet, and S. S. Romañach. 2007. Economic and conservation significance of the trophy hunting industry in sub-Saharan Africa. Biological Conservation 134(4):455-469.

Lipper, L., and R. Cavatassi. 2004. Land-use change, carbon sequestration and poverty alleviation. Environmental Management 33(S1): S374-S387.

Locatelli, B., L. Pedroni, and Z. Salinas. 2008. Design issues in clean development mechanism forestry projects. Pages 107-121 in C. Streck, R. O'Sullivan, T. Janson-Smith, and R. G. Tarasofsky, editors. Climate change and forests: emerging policy and market opportunities. Brookings Institution Press, Baltimore, Maryland, USA.

Molnar, A., M. Liddle, C. Bracer, A. Khare, A. White, and J. Bull. 2007. Community-based forest enterprises: their status and potential in tropical countries. ITTO Technical Series Number 28. International Tropical Timber Organization, Yokohama, Japan. [online] URL: http://www.right sandresources.org/documents/files/doc 109.pdf.

Molnar, K., S. J. Scherr, and A. Khare. 2004. Who conserves the world's forests? Community-driven strategies to protect forests and respect rights. Forest Trends and Ecoagriculture Partners, Washington, D.C., USA. [online] URL: http://www .rightsandresources.org/documents/files/doc 136.pdf

Muñoz-Piña, C., A. Guevara, J. M. Torres, and J. Braña. 2008. Paying for the hydrological services of Mexico's forests: analysis, negotiations and results. Ecological Economics 65(4):725-736.

Nelson, A., and K. M. Chomitz. 2007. The foresthydrology-poverty nexus in Central America: an heuristic analysis. Environment, Development and Sustainability 9(4):369-385.

Pagiola, S. 2008. Payments for environmental services in Costa Rica. Ecological Economics 65 (4):712-724.

Pagiola, S., P. Agostini, J. Gobbi, C. de Haan, M. Ibrahim, E. Murgueitio, E. Ramírez, M. Rosales, and J. P. Ruíz. 2004. Paying for biodiversity conservation services in agricultural landscapes. World Bank Environment Department Paper Number 96. World Bank, Washington, D.C., USA. [online] URL: ftp://ftp.fao.org/docrep/nonfao/lead/ x6154e/x6154e00.pdf.

Pagiola, S., A. Arcenas, and G. Platais. 2005. Can payments for environmental services help reduce poverty? An exploration of the issues and the evidence to date from Latin America. World Development 33(2):237-253.

Pagiola, S., A. R. Rios, and A. Arcenas. $2008 a$. Can the poor participate in payments for environmental services? Lessons from the Silvopastoral Project in Nicaragua. Environment and Development Economics 13(3):299-325.

Pagiola, S., W. Zhang, and A. Colom. $2008 b$. Assessing the potential for payments for watershed services to reduce poverty in Guatemala. In American Agricultural Economics Association 2008 Annual Meeting (Orlando, 2008). American Agricultural Economics Association, Milwaukee, 
Wisconsin, USA. [online] URL: http://ageconsearch. umn.edu/handle/42932.

Peskett, L., D. Huberman, E. Bowen-Jones, G. Edwards, and J. Brown. 2008. Making REDD work for the poor. Poverty Environment Partnership, International Union for Conservation of Nature, Gland, Switzerland. [online] URL: http: //www.unep-wcmc.org/climate/pdf/Making\%20REDD\% 20work\%20for\%20the\%20poor\%20FINAL \%20DRAFT $\%$ 200110.pdf.

Porras, I., M. Grieg-Gran, and N. Neves. 2008. All that glitters: a review of payments for watershed services in developing countries. International Institute for Environment and Development, London, UK.

Scherr, S. J., and J. A. McNeely. 2008. Biodiversity conservation and agricultural sustainability: towards a new paradigm of 'ecoagriculture' landscapes. Philosophical Transactions of The Royal Society B 363(1491):477-494.

Scherr, S. J., J. C. Milder, and M. Inbar. 2007a. Paying farmers for stewardship. Pages 378-398 in S. J. Scherr and J. A. McNeely, editors. Farming with nature: the science and practice of ecoagriculture. Island Press, Washington, D.C., USA.

Scherr, S. J., J. C. Milder, L. Lipper, and M. Zurik. 2007b. Payments for ecosystem services: potential contributions to smallholder agriculture in developing countries. Ecoagriculture Partnersand Food and Agriculture Organization, Washington, D.C., USA, and Rome, Italy.

Scherr, S. J., and S. Sthapit. 2009. Mitigating climate change through food and land use. Worldwatch Report 179. Worldwatch Institute, Washington, D.C., USA.

Scherr, S. J., A. White, and D. Kaimowitz. 2004. A new agenda for forest conservation and poverty reduction: making markets work for low-income producers. Forest Trends, Washington, D.C., USA. [online] URL: http://www.forest-trends.org/publica tion details.php?publicationID $=100$.

Smith, J., and S. J. Scherr. 2003. Capturing the value of forest carbon for local livelihoods. World Development 31(12):2143-2160.
Southgate, D., and S. Wunder. 2007. Paying for watershed services in Latin America: a review of current initiatives. Working Paper Number 07-07. Sustainable Agriculture and Natural Resource Management Collaborative Research Support Program, Blacksburg, Virginia, USA. [online] URL: http://www.oired.vt.edu/sanremcrsp/documents/ PES.Sourcebook.Oct.2007/Sept.2007.PESLatinAmerica. pdf.

Streck, C., R. O'Sullivan, T. Janson-Smith, and R. G. Tarasofsky. 2008. Climate change and forestry: an introduction. Pages 3-10 in C. Streck, R. O'Sullivan, T. Janson-Smith, and R. G. Tarasofsky, editors. Climate change and forests: emerging policy and market opportunities. Brookings Institution Press, Baltimore, Maryland, USA.

Sunderlin, W. D., S. Dewi, and A. Puntodewo. 2007. Poverty and forests: multi-country analysis of spatial association and proposed policy solutions. CIFOR Occasional Paper Number 47. Center for International Forestry Research, Bogor, Indonesia. [online] URL: http://www.cifor.cgiar.org/ Knowledge/Publications/Detail?pid=2294.

Sunderlin, W. D., J. Hatcher, and M. Liddle. 2008. From exclusion to ownership? Challenges and opportunities in advancing forest tenure reform. Rights and Resources Institute, Washington, D.C., USA. [online] URL: http://www.rightsandresources. org/publication details.php?publicationID=736.

Swallow, B. M., M. F. Kallesoe, U. A. Iftikhar, M. van Noordwijk, C. Bracer, S. J. Scherr, K. V. Raju, S. V. Poats, A. Kumar Duraiappah, B. O. Ochieng, H. Mallee, and R. Rumley. 2009. Compensation and rewards for environmental services in the developing world: framing pantropical analysis and comparison. Ecology and Society 14(2): 26. [online] URL: http://www.ecolog yandsociety.org/vol14/iss2/art26/.

Swallow, B., R. Meinzen-Dick, and M. van Noordwijk. 2005. Localizing demand and supply of environmental services: interaction with property rights, collective action, and the welfare of the poor. CAPRi Working Paper Number 42. IFPRI and World Agroforestry Centre, Washington, D.C., USA. [online] URL: http://www.capri.cgiar.org/wp/ capriwp42.asp. 
ten Kate, K., J. Bishop, and R. Bayon. 2004. Biodiversity offsets: views, experience, and the business case. International Union for Conservation of Nature and Insight Investment, Gland, Switzerland, and London, UK. [online] URL: http: //cmsdata.iucn.org/downloads/bdoffsets.pdf.

Turpie, J. K., C. Marais, and J. N. Blignaut. 2008. The working for water programme: evolution of a payments for ecosystem services mechanism that addresses both poverty and ecosystem service delivery in South Africa. Ecological Economics 65 (4):788-798.

Uchida, E., J. Xu, Z. Xu, and S. Rozelle. 2007. Are the poor benefiting from China's land conservation program? Environment and Development Economics 12(4):593-620.

van Noordwijk, M., B. Leimona, L. Emerton, T. P. Tomich, S. J. Velarde, M. F. Kallesoe, M. Sekher, and B. M. Swallow. 2007. Criteria and indicators for environmental service compensation and reward mechanisms: realistic, voluntary, conditional and pro-poor. ICRAF Working Paper Number 37. World Agroforestry Centre, Nairobi, Kenya.

World Bank. 2007. Carbon finance for sustainable development. World Bank, Washington, D.C., USA. [online] URL: http://wbcarbonfinance.org/Ro uter.cfm?Page=DocLib\&CatalogID=37197.

World Travel and Tourism Council. 2008. Continued growth signalled for travel and tourism industry. Press Release. World Travel and Tourism Council, Berlin, Germany. [online] URL: http://ww w.wttc.travel/eng/Tourism News/Press Releases/ Press Releases 2008/ Continued growth signalle $\mathrm{d}$ for Travel and Tourism Industry.

Wunder, S. 2005. Payments for environmental services: some nuts and bolts. CIFOR Occasional Paper Number 42. Centre for International Forestry Research, Bogor, Indonesia.

Wunder, S. 2008. Payments for environmental services and the poor: concepts and preliminary evidence. Environment and Development Economics 13(3):279-297.

Wunder, S., and M. Albán. 2007. Decentralized payments for environmental services: the cases of
Pimampiro and PROFAFOR in Ecuador. Ecological Economics 65(4):685-698.

Wunder, S., B. D. The, and E. Ibarra. 2005. Payment is good, control is better: why payments for environmental services in Vietnam have so far remained incipient. Centre for International Forestry Research, Bogor, Indonesia. [online] URL: http://www.cifor.cgiar.org/Knowledge/Publications/ Detail?pid=1912.

Zilberman, D., L. Lipper, and N. McCarthy. 2008. When could payments for environmental services benefit the poor? Environment and Development Economics 13(3):255-278. 